\title{
Referans Grupları ile İletişimin Satın Alma Kararları Üzerine Etkisi: Genç Yetişkinlere Yönelik Bir Araştırma
}

\author{
Yasemin KARACA \\ doktora sonrası araştırmacı, université libre de Bruxelles \\ yaseminkaraca2000@gmail.com
}

\begin{abstract}
The Influence of Communication With Reference Groups on Purchase Decisions: A Survey on Young Adults

This study has been carried out to identify the nature of the reference group influence which affect consumer behaviour, on purchasing decisions of the individual. It elaborates on the reference groups' influence among young adults and consequently their product purchase decisions. This study particularly focuses on peer groups described as reference group and product purchase decisions resulting from communication among peer groups. For this purpose, a survey was conducted on the students of the University of Suleyman Demirel. The findings of the survey reveal that there are informational and normative reference group influence on product purchase decisions and these influences vary across public necessity, private necessity, private luxury and public luxury products purchase decisions.
\end{abstract}

keywords: group, reference groups, buying behavior. 


\section{Résumé}

\section{L'Influence de Communication avec les Groupes de Référence sur les Décisions d'Achat: Une Recherche chez les Jeunes Adultes}

Cet article est réalisé afin d'identifier la nature de l'influence de groupe de référence qui affecte les comportements de consumers, sur les décisions individuelles d'achat. II élabore plus précisément l'influence des groupes de référence chez les jeunes adultes et par conséquent leurs décisions d'achat. Cette étude se concentre particulièrement sur les groupes de pairs décrits comme groupe de référence et les décisions d'achat de produits résultant de la communication entre les groupes de pairs. À cette fin, une enquête a été menée sur les étudiants de I'Université de Suleyman Demirel. Les résultats de cet enquête indiquent qu'il y a une certaine influence informative et normative des groupes de référence sur les décisions d'achat et ces influences varient selon les décisions d'achat des nécessités publiques, des nécessité privées et des produits de luxe publiques et privés.

mots-clés: groupes, groupes de référence, comportements d'achat

\section{Öz}

Bu çalışma, tüketici davranışlarını etkileyen referans gruplarının, bireyin satın alma kararları üzerinde ne tür bir etkiye sahip olduğunu ortaya çıkarmak amacıyla gerçekleştirilmiştir. Çalışmada, genç yetişkinlerin referans gruplarından etkilenme durumu ve buna bağlı olarak ürünleri satın alma kararları üzerinde durulmuştur. Özellikle, referans grubu olarak nitelendirilen arkadaş grupları ve arkadaş grupları arasındaki iletişimden kaynaklı, ürün satın alma kararlarına odaklanılmaktadır. Bu amacı gerçekleştirmek için Süleyman Demirel Üniversitesi öğrencilerine yönelik bir anket çalışması yapılmıştır. Çalışmanın sonuçlarına göre; referans gruplarının, genç yetişkinlerin satın alma kararları üzerinde bilgilendirici ve normatif etkileri bulunduğu ve bu etkilerin kamusal gerekli, özel gerekli, özel lüks, kamusal lüks ürünlerin satın alınması kararlarında değiştiği tespit edilmiştir.

anahtar kelimeler: grup, referans grupları, satın alma davranışı 


\section{Giriş}

Son yıllarda tüketici davranışları araştırmalarında, gençlerin birer tüketici olarak nasıl davrandıkları ve yetişkin birer tüketici oluncaya kadar, nasıl bir değişim sergiledikleri hem işletme hem de pazarlama uygulayıcıları açısından önem arz etmektedir (Eskiler vd. , 2016, s. 710). Dolayısıyla gençler, toplumda gittikçe artan sayıları, oluşturdukları güçlü pazar etkisi, alışveriş yaklaşımları ve karar verme süreçleri ile pazarlamacıların ve araştırmacıların ilgisini çekmektedirler (Kamaruddin ve Mokhlis, 2003, s. 146). Gençlerin pazarlamacılar açısından son derece önemli bir hedef pazar olmasının nedenleri olarak; aile harcamalarını etkilemeleri, gelecekte harcayacakları para ve gençlik trendlerinin yükselişte olması gösterilmektedir (Martin ve Bush, 2000, s. 441; Ünal ve Erciş, 2007, s. 325).

Genç bireylerin satın alma davranışlarını gerçekleştirirken karar vermelerinde etkili olan sosyal faktörlerden biri referans gruplarıdır. Gençlerin satın alma davranışlarını etkilemesi ve tüketici olarak sosyalleşmesinde referans grupları içerisindeki iletişim önemlidir. Referans grupları, bireylere fikirlerini yayarak, grupla bütünleşmelerini sağlamak amacıyla, bireylerin kararlarında baskı oluşturmaktadır. Referans grupları; bireyin etkilendiği sanatçılar, spor kahramanları, siyasi liderler, ebeveynler, iş arkadaşları, öğretmenler ve içinde bulunduğu arkadaş gruplarıdır (Makgosa ve Mohube, 2007, s. 64). Referans gruplarının birey üzerindeki etkisi özellikle tüketici davranışlarını inceleyen pazarlamacılar açısından önem arz etmektedir. Örneğin, bireyin ürün satın alma kararlarını şekillendirmede referans grubu etkisinin oynadığı rolü bilmek pazarlamacılara etkili tanıtım stratejileri uygulamalarına yardım edebilir. Bu bağlamda; genç tüketicilerin referans gruplarıyla iletişiminin satın alma davranışlarına etkisinin analiz edilmesi araştırmanın temelini oluşturmaktadır.

Dolayısıyla bu çalışmanın amacı, referans gruplarından arkadaş grupları ile genç yetişkin bireylerin satın alma kararları arasındaki ilişkiyi incelemektir.

Bu amaç doğrultusunda, mevcut çalışmada öncelikle referans gruplarının tanım ve kapsamına ve bireye olan etkilerine değinilmiştir. Bearden ve Etzel (1982), Childers ve Rao (1992) ve Makgosa ve Mohube (2007) tarafından yapılan geçmişteki çalışmalar temel alınarak, Türkiye açısından referans gruplarından arkadaş gruplarının, satın alma kararları üzerindeki etkileri ürün kategorisi kapsamında üniversite öğrencileri açısından incelenmiştir. Özellikle, Bearden ve Etzel (1982), Childers ve Rao (1992) ve Makgosa ve Mohube (2007) tarafından dönemsel olarak tekrarlanmış, benzer araştırma modeli kurularak gerçekleştirilen çalışmaların her dönemde farklı sonuçlara ulaşılması ve sonrasında (2007 sonrasında) benzer ölçeklerle bu tür bir çalışmanın yapılmamış olması, bu çalışmanın, mevcut dönemde değişimlerin gözlemlenmesi, literatüre katkı sağlaması açısından önemlidir. Ayrıca uluslararası literatürde oluşturulan mevcut modelin, Türkiye'deki genç bireyler açısından yansımalarının neler olduğunun 
belirlenmesi, buna benzer bir çalışmanın Türkiye'de daha önce yapılmamasından dolayı, bu çalışma ile uygulamaya katkı sağlayacağı ve uluslararası bir karşılaştırma olanağı sunacağı düşünülmektedir. Ayrıca bu araştırma, genç bireyler tarafından tüketilen ürünlerde, referans gruplarından arkadaş grubu etkisinin nasıl değişebileceği konusundaki değerlendirmemize katkıda bulunarak; işletmelerin pazarlama kampanyalarına veya genç yetişkin tüketicileri hedef pazar olarak seçen pazarlamacılara referans olabilmesi açısından da önemlidir.

Bu nedenle referans gruplarından biri olan arkadaş grupları ile genç yetişkin bireylerin satın alma kararları arasında ne tür bir ilişki olduğunu ortaya çıkarmak amacıyla, Süleyman Demirel Üniversitesi öğrencilerine yönelik ampirik bir çalışma yapılmıştır. Veriler anket yöntemiyle toplanmış ve sonuçlar mevcut literatüre katkı sağlayacak biçimde yorumlanmıştır.

\section{Referans Grupları Tanım ve Kapsamı}

Genel amaçlara ulaşmak için, karşııklı tesir ilişkilerine girişen ve aynı topluluğa ait olma duygusuna sahip bulunan birden fazla insanın meydana getirdiği sosyal bütüne grup denmektedir (İşçi, 1999, s. 20). Grup, birbirleriyle (az çok) belirli statü ve rol iliş̧kileri içinde bulunan kişilerden oluşan ve en azından grubu ilgilendiren önemli meselelerde üyelerin davranışını düzenleyen, kendine ait bir dizi değer ve normu olan sosyal bir birimdir (Şerif ve Şerif, 1996, s. 144; Gönüllü, 2001, s. 191). Bireyler, bu gruplara duygusal ve bilişsel olarak bağlanmakta, diğer grup üyeleriyle özdeşim kurmakta ve grubun kurallarına uymaktadır. Bu gruplardan en önemlisi tüketici davranışlarını etkileyen ve şekillendiren sosyal faktörler kapsamında yer alan referans gruplarıdır. Bireyler, sosyo-kültürel etkinliklere referans grupları içerisinde katılmakta ve grup kültüründen etkilenmektedir. Referans grupların bireye değer katma etkisi, bireyin bir gruba psikolojik uyum intiyacından kaynaklanmaktadır (Şener ve Tunçbilek, 2014, s. 3).

Referans grubu tanımı ise Hyman (1942) tarafından, sosyal statü ile ilgili yaptığı bir çalışmada araştırmaya katılanlara kendilerini hangi bireyler veya gruplarla karşılaştırdıklarını sorduğunda bulunmuştur. Bu ilk tanımlamayı, kavramı açığa kavuşturan ve genişleten ek araştırmalar ve birçok yeni bulgular izlemiştir. Örneğin, Kelley (1947), referans gruplarını karşılaştırma standartlarını kendini takdir etmek için kullananlar ve kişisel normlara, tutum ve değerlere kaynak olarak kullananlar olmak üzere ayırmıştır. Literatürün bu şekilde genişlemesi birçok alanda çeşitli uygulamalar yapılmasına temel hazırlamıştır. Örneğin, Hyman ve Singer (1968) bu kavramı çiftçiler, bilim insanları, alkolikler, gazeteciler, akıl hastaları, tüketiciler, seçmenler, suçlu çocuklar ve fikir liderleri üstünde uygulamışlardır (aktaran Bearden ve Etzel, 1982, s. 183).

Referans grupları, bireyin davranışlarını ve kendini değerlendirdiği, örnek aldığı gruplardır (Özkalp, 2000, s. 89). Referans grupları, kişilerin satın alma kararlarında değer hükümleri olarak işlev gören gruplardır (Odabaşı, 1998, s. 104). 
Referans grubu, kişinin tutumlarını, fikirlerini, değer yargılarını ve davranışlarını doğrudan veya dolaylı olarak etkileyen bir insan topluluğudur. Bu grup, aile ve diğer yüz yüze ilişkilerin olduğu yakın çevre (arkadaşlar, komşular, meslektaşlar, kurum ve kuruluşlar vb.) ile kişinin üyesi olmadığı gruplar ve doğrudan ilişkisi olmayan kişilerden (artistler, şarkıcılar, sporcular vb.) oluşur. Referans grupları, "üyelik", "özlem"" ve "istenmeyen" gruplar olarak ayrilır (Tek, 1997, s. 201).

Referans grupları, tüketici için önemli olan ve bireyin tutum ve davranışlarını şekillendiren sosyal gruplar olarak tanımlanır (Hsu vd., 2006, s. 475).

Bir referans grubu, değerleri ve tutumları bir birey tarafından kendi davranışına esas alarak kullanılan gruptur. Araştırmacıların ve pazarlamacıların özellikle ilgisi normatif referans grupları ve karşılaştırmalı referans gruplarıdır. Karşılaştırmalı referans grupları bireyin kendini değerlendirme için kullandığı gruplar olarak tanımlanır. Normatif gruplar ise kişisel normlar, tutumlar ve değerler kaynağı olarak kullanılan gruplardır. Normatif referans gruplara, bireylere dolaylı etkileşim yoluyla normlar, değerler ve tutumlar sunan ebeveynler, iş arkadaşları, öğretmenler ve akranlar dâhildir. (Childers ve Rao, 1992, s. 198; Bristol ve Mangleburg, 2005, s. 80; Haroon ve Haq, 2015, s. 246). Karşılaştırmalı referans grupları ise; bireyin özendiği ve hayranlık duyduğu ama nispeten bireyden ya da sosyal olarak daha uzak olduğu, başarı standartları sunan spor kahramanları ve eğlence figürleridir (Martin ve Bush, 2000, s. 441; Makgosa ve Mohube, 2007, s. 64, Eskiler vd., 2016, s. 710).

\section{Referans Gruplarının Satın Alma Davranışlarına Etkisi}

Tüketici davranışı perspektifinden bakıldığında, referans grupları, bireyi; bilgilendirdiği, belirli ürün ve markadan haberdar ettiği ayrıca bireylerin kendi düşünce ve tutumlarını, grubun tutum ve davranışı ile karşılaştırma şansı verdiğinden ve grubun norm ve standartları ile uyumlu hale getirdiğinden dolayı önemlidir (Makgosa ve Mohube, 2007, s. 64; Demir, 2011, s. 268).

Referans grupları, ürün satın alma sürecinde bireye gerekli olan bilgiyi sunarak katkı sağlamaktadır. Bireyin satın aldığı ürün ile diğer bireyler arasında kişisel imajını geliştirmesi, referans grupların etkisini ortaya koymaktadır. Ayrıca, bireyler ürün satın alma kararını grup üyelerinin beklentilerine göre şekillendirmektedir (Bearden ve Etzel, 1982, s. 187). Bireyin satın alma kararlarının \%80'ninin başka birinin doğrudan önerisi ile etkilenerek gerçekleşmiş olduğu belirlenmiştir (Hsu vd. 2006, s. 474).

Referans grupları; bireyin, gruba uymak istediği için tutumunu ve kendine ilişkin görüşünü etkiler, bireye yeni yaşam stillerini gösterir ve yaşam tarzını oluşturan ürün ve marka seçimini etkileyecek şekilde bireyi gruba uymaya zorlamaktadır (Tek, 1997, s. 201; Carter vd., 2003, s. 225). 
Geçmişte yapılan çalışmalarda da referans gruplarının satın alma, tüketim kararlarına etkisi ortaya çıkmıştır. Küresel markalara karşı Çinli genç tüketicilerin tutumlarının şekillenmesinde referans grubun etkisini araştıran bir çalışmada, katılımcıların küresel markalara karşı olumlu tutumlarında referans gruplarının etkisinin güçlü olduğu belirlenmiştir (Huang ve Chu, 2008, s. 10). Yat limanı müşterilerinin kulaktan kulağa iletişime bağlı satın alma kararları üzerinde referans gruplarının bir etkisinin bulunup bulunmadığının incelendiği bir diğer araştırmada ise, yat limanı müşterilerinin kulaktan kulağa iletişime bağlı satın alma kararları üzerinde diğer müşterilerin söylediklerinin anlamlı bir etkisinin olduğu belirlenmiştir (Arlı, 2012, s. 155). Şener ve Tunçbilek (2014, s. 3) tarafından, genç tüketicilerin sembolik tüketim davranışlarının gönüllü katılım yoluyla belirli bir referans gruba üyeliklerine göre farklılık gösterip göstermediğini belirlemek amacıyla yapılan çalışmada; öğrencilerin sembolik tüketim davranışlarının, özellikle gönüllü katılım yoluyla bir referans gruba üyeliklerine göre farklılık gösterdiği ve sembolik tüketimden beklenen faydanın daha fazla olduğu tespit edilmiştir. Araştırma sonucunda gönüllü katılım yoluyla belirli referans gruplara üye olan öğrencilerin gönüllü katılım yoluyla belirli bir referans gruba üye olmayan öğrencilere göre sembolik tüketim davranışlarının daha fazla olduğu sonucu elde edilmektedir. Yapılan bir diğer çalışmada da ev hanımları ve öğrencilerden oluşan iki farklı grup, sırasıyla, referans grup etkisi açısından incelenmiştir. Sonuçlar, referans gruplarının üç tip marka seçimi üzerine olan etkisi açısından, ev kadınları ve öğrenciler arasında önemli farklılıklar olduğunu ortaya koymaktadır (Park ve Lessig, 1977, s. 102). ABD ve Çin'in cep telefonu kullanıcıları arasında tüketici satın alma davranışları üzerinde farklı referans grubun etkisini araştıran karşılaştırmalı bir çalışmada ise, incelenen üç referans grup etkisini ortaya koymaktadır. Çalışmada, Çin ve ABD cep telefonu alıcıları üzerinde referans grubunun faydacı etkisi diğer iki referans grup etkileri arasında istatistiksel olarak anlamlı fark olduğunu ortaya koymaktadır, bilgi ve değer ifadenin, tüketiciler üzerinde göreceli önemsiz etkileri bulunduğu ortaya çıkmıştır (Yang vd. , 2007, s. 319). Deneysel sanal toplulukların, bireyin alışveriş tercihlerini nasıl etkilediğini sosyal etki modeliyle test eden farklı bir referans grubu etkisini ölçmeye çalışan çalışmada ise, toplumsal kimlik ve normlar içeren sanal toplulukların, üyeleri üzerindeki etkilerinin söz konusu olduğu ve bireyi alışveriş seçenekleri açısından motive ettikleri belirlenmiştir (Pentina vd. , 2008, s. 114). Tasarım etiketli kıyafetlerin satın alınması kararlarına etki eden referans gruplarını belirlemek üzere yapılan bir araştırmada, referans gruplarının farklı düzeylerde satın alma kararlarını etkiledikleri tespit edilmiştir. (Eze vd., 2012, s. 52). Ayrıca yapılan bir başka çalışmada da, referans grubu üyeleri tarafından yapılan önerilerin, bireyin bu önerileri kabul etme ve grupla uzlaşma yönünde önemli bir etkiye sahip olduğu belirlenmiştir (Chuang vd. , 2012, s. 554). Tüketicinin marka seçimi çalışmasında Witt (1969), gruba bağlıı̆̆ın davranışı etkilediğini doğrulamıştır. Grupların geniş kapsamlı etkisi, sosyal olarak uzakta olan referans grupları eğer tüketiciler o gruptaki kişilere ve aktivitelere karşı uygun tutumlar sergiliyorsa tüketicileri etkileyebilir fikrini savunan Cocanongher ve Bruce (1971) tarafından öne sürülmüştür. Bir farklı araştırmada da Witt ve Bruce (1970) sosyal bağlılık kapsamında ürünleri inceleyerek grup etkisinin varlığını 
ortaya koymuştur. Stafford (1966) bireysel marka seçiminin gruplar tarafından etkilendiğini bulmuştur (aktaran Bearden ve Etzel, 1982, s. 183). Kitlesel tüketilen ürünlerin satın alınmasında akran etkisinin incelendiği bir araştırmada ise özellikle etkinlikler ve festivallerle ilgilenen üniversite öğrencilerinin etkinliğe katılmak için başka bir kişiyi etkilemeye çalıştığında, kişilerarası etkinin güçlü olduğu tespit edilmiştir (Scully ve Motial, 2016, s. 46).

Özetlersek; referans grupları tüketicinin davranışı üzerinde üç önemli etkide bulunmaktadır. Bunlar, normlandırıcı, kimliklendirici ve bilgilendirici etkilerdir (Odabaşı, 1998, s. 105). Aynı zamanda, referans gruplarının etkisi, tüketici araştırmalarında bilgilendirici, faydacı ve değer ifade edici olarak üç şekilde tespit edilmiştir (Park ve Lessig, 1977, s. 102). Bilgilendirici etkide, bir kişinin çevre bilgisi ve/veya çevrenin boyutlarıyla başa çıkma yeteneği zenginleştirici olarak algılanır. Bilgilendirici etki, aynı zamanda başkalarının davranışlarını gözlemlemeyi veya aktif olarak uygun uzmanlığa sahip başkalarından bilgi araştırmayı gerektirir. Bilgilendirici etki, bir bireyi eğer o birey gerçeklik hakkında kanıt olarak başkalarından bilgi kabul eder ve bilinçli kararlar vermek isterse etkileyebilir. Gençlerin arkadaşlarıyla alışveriş yapma nedenlerinin incelendiği bir çalışmanın sonuçlarına göre, gençlerin özellikle bir ürün/hizmet satın alma sürecinde arkadaşlarından bilgi edinme yönünde duyarlı oldukları tespit edilmiştir (Mangleburg vd., 2004, s. 101).

Tüketiciler ürün/hizmet satın alma davranışlarında genellikle riski azaltmak için bilgi toplarlar. Pazarlama yöneticileri ve teorisyenleri için risk alma eğilimi veya algılanan risk üzerinde yoğunlukla durulan bir alandır. Çünkü risk, bireyin satın alma davranışını etkileyen önemli bir kavramdır (Aydın, 2009, s. 191). Genel olarak bir ürünün tüketici açısından ifade ettiği risk derecesi arttıkça o ürüne karşı ilgilenim miktarı da artar. Böyle bir durumda tüketicinin satın aldığı bilgisayar veya takım elbise, evine aldığı mobilyadan daha fazla sosyal risk veya psikolojik risk taşıdığı için daha fazla ilgilenime yol açabilir (Koç, 2012, s. 216). Tüketiciler, satın alacakları ürünün ilgilenim düzeyine (düşük/yüksek ilgilenim), sosyal çevrelerce fark edilme intiyacının doğurduğu baskıya ve işletmelerin pazarlama faaliyetlerine de bağlı olarak çoğu kez birçok karmaşık alternatifler arasından seçim yapmak zorunda kalmaktadırlar (Çakır, 2007, s. 163; Çilingir ve Yıldız, 2010, s. 80). Gençlerde, ürün ilgilenimini etkileyen değişkenlerin incelendiği bir araştırmada genç çocukların ürün ilgilenim seviyelerinin aileler ve diğerleri tarafından etkilendiği, çocukların ürün ilgilenim seviyelerinin arkadaş ve ürün kategorisinden etkilendiği, ergenlerin ise ürün ilgilenimlerinin, ürün bilgisi ve ürün kategorisine dayandığı tespit edilmiştir (Harari ve Hornik, 2010, s. 499).

Faydacı etki bireyin cezadan kaçınmak veya ödüle ulaşmak için diğerlerinin tercihlerine ve beklentilerine uyduğunda oluşur. Bu durum, bireyin diğerlerinin önemli ödül veya ceza verme kabiliyetine sahip olduğunu algıladığında oluşur, birey kendi davranışının başkaları tarafından bilineceğine inanır ve cezadan kaçınmak veya ödülü elde etmek için motive edilir. Diğer bir deyişle, tüketiciler 
referans gruplarına faydalı bilgi edinmek için, ödüle ulaşmak veya cezadan kaçınmak için ve benlik anlayışlarını oluşturmak, sürdürmek veya değiştirmek için uyum göstermektedirler (Koç, 2012, s. 360).

Değer ifade edici etki ise benlik kavramı geliştirmek için bireyin isteği ile ilgilidir. Benlik son derece duygu yüklüdür ve benlikle ilgili olan her şey duygusal ilgilenime neden olabilmektedir. (Kandemirvd., 2013, s. 25). Insanların etraflarındaki olayların, nesnelerin veya ürünlerin onlar için önem derecesi ve kendileriyle alakalı olup olmamaları değişik zaman ve durumlarda farklııklar gösterebilir (Koç, 2012, s. 208). Değer ifade edici etkinin, bireyin egosunu geliştirme arzusundan dolayı bireyi etkileme intimali vardır. İnsanlar benlik ve kişiliklerine uygun, kişiliklerini yansıtan veya tamamlayan ürün ve hizmetleri tüketerek dış dünyaya benlikleri, kişilikleri ve oluşturmak istedikleri imajla ilgili mesajlar verirler. Ürünler ve markalar onları satın alan bireyin kişiliğinin uzantısı olarak görülebilir (Koç, 2012, s. 260). Satın alma davranışlarında arkadaşlarının etkisi gençler için bir kimlik geliştirme işleminin önemli bir parçası olarak görünmektedir (Mangleburg vd., 2004, s. 101).

Satın alma kararları üzerinde referans grup etkisinin önemli bir diğer faktörü Bourne (1957) göre, kamu tüketim ve özellikli olarak o ürünün görünürlüğüdür. Daha sonra, Bearden ve Etzel (1982, s. 184) bu iki boyutu özel, kamu tüketimi ve lüks, zorunlu ürün oluşturarak ele almıştır. Satın alınan ürünlerin çeşitleri, bu ürünlerle ilgili risk algılama dereceleri ve satın alma karar tiplerinin yanı sıra başka faktörler de satın alma kararını etkileyebilmektedir. Örneğin, yamaç paraşütü ve bungee jumping yapan kişilerin risk alma eğilimleri yüksektir ve risk arayıcılar olarak tanımladığımız tüketici grubuna girerler. Öte yandan, tatillerini güven içinde geçirmek için devamlı olarak satın aldıkları paket tatilleri seçen insanlar riskten kaçınan insanlardır. Risk algılaması bir ürünü satın almada gösterilen çaba ile de yakından ilgilidir (Koç, 2012, s. 111).

\section{Araştırmanın Amacı}

Çalışmanın amacı, genç yetişkin bireylerin, dâhil oldukları arkadaş gruplarının ve bu gruplarla iletişimden kaynaklı olarak, ürün satın alma kararlarına olan etkisini belirlemektir. Genel olarak, incelenen literatür, referans gruplarının etkisinin ürün satın alma kararlarında önemli rol oynadığını ortaya koymuştur. Referans grupları, genelde aile, arkadaş grubu, biçimsel sosyal gruplar olarak tanımlanmaktadır (Odabaşı, 1998, s. 104; Koç, 2012, s. 359). Ancak, bu çalışmada bireyi özellikle satın alma kararları üzerinde yüksek etkisi olabileceği düşünülen, üniversite öğrencilerinin iletişimde oldukları arkadaş gruplarının etkisini araştırmaya odaklanıımıştır. Özellikle üniversite öğrencilerine yönelik odaklanmanın nedeni; üniversitelerin yerel ekonomik gelişmelere katkıları yadsınamayacak kadar büyük olmasıdır. Özellikle kentleşmenin tam olarak gerçekleştirilemediği bölgelerde kurulan üniversitelerin, bulundukları bölgenin ekonomik ve sosyal gelişmişlik düzeyinin artırılmasında önemli işlevler gördügü görülmektedir. Üniversiteler, hem kendi harcamaları, hem de çalışan-öğrenci-ziyaretçi harcamaları ile yöredeki pek çok sektöre etki etmektedir. Üniversite bağlantılı harcamaların etki ettiği 
sektörler, tarım ve hayvancılık, giyim, kırtasiye, sağlık, ulaşım, telekomünikasyon, elektrik-gaz gibi hizmetler, bankalar, barınma, yiyecek ve içecek sektörü gibi çok geniş bir yelpazeyi kapsamaktadır (Akçakanat vd., 2010, s. 176).

Bu nedenle mevcut araştırmada; genç birey olarak nitelendirilen, üniversite öğrencilerinin satın alma kararlarına iletişimde oldukları referans gruplarının etkisi, ürün kategorisi kapsamında tespit edilmeye çalışılmışıı.

\section{Araştırmanın Tasarımı}

Yukarıda ifade edilen amaca ulaşabilmek için araştırmada şu temel sorunun cevabı aranmaktadır. Referans grupları ile genç yetişkin bireyin satın alma kararları arasında ne tür bir ilişki vardır? Bu temel sorunun daha iyi anlaşımasına yardımcı olması için şu alt sorularında araştırma cevabı aranmaktadır. Tüketilen bir ürünün tercihinde bu ürünün lüks/kamusal (genel) veya özel/gerekli (zorunlu) olması durumunda referans grupları nasıl bir etki yaratmaktadır.

Literatürde tanınan iki baskın etki bilgilendirme ve normatif etkidir. Bilgilendirici etki, gerçeklik hakkında kanıt olarak diğerlerinden bilgileri kabul etmek eğilimini ifade eder. Normatif etki ise, diğerlerinden beklentileri ile uyum içinde olma eğilimini ifade etmektedir. Park ve Lessig (1977) tarafından yapılan çalışmada, normatif etkinin anlamlı değer ve faydacı etkiler olmak üzere iki farklı boyutta ayrışması önerilmiştir: Araştırmacılar tarafından, referans grubun bilgi amaçlı, faydacı ve anlamlı değer etkilerinin tüketicilerin hassasiyeti üzerinde göze çarpan ürünlerin etkisini incelemek için, bu ölçekler kullanılmıştır (Bearden ve Etzel, 1982; Childers ve Rao, 1992; Makgosa ve Mohube, 2007). Bizim çalışmamızda da bu etki, iki boyutta ele alınarak, mevcut dört farklı ürün kategorisinde genç yetişkinlerin normatif (anlamlı değer, faydacı) ve bilgilendirici etkileri değerlendirilmiştir.

Bearden ve Etzel (1982), Childers ve Rao (1992), Makgosa ve Mohube, (2007) tarafından önerilen referans gruplarının ürün ve marka etkisindeki dörtlü ayrım, çalışmalarında ele alınmıştır. Bearden ve Etzel (1982) konuya, kamu önünde tüketim ve özel tüketim boyutu ile intiyacın lükslüğü ve zorunluluğu açısından yaklaşmışlardır. Childers ve Rao (1992), ürünün/markanın lükslüğü ve zorunluluğu boyutlarına akranların ve ailenin etkisini de dâhil etmişlerdir. Makgosa ve Mohube (2007) ise sonraki dönemde tekrardan bu iki yazarın çalışmalarını ele almış ve yeniden değerlendirmiştir. Çalışmamızda kullandığımız ürün kategorileri tanımlamaları aşağıdaki şekilde Tablo 1.'de belirtilmiştir. 


\section{Tablo 1. Dört Tip Ürün Kategorisi}

\section{Halka açık olarak (kamusal) tüketilen lüks ürünler:}

Tüketilirken gözlemlenen ve yaygın olarak sahip olunamayan veya kullanılamayan ürünler. Bu ürünler ayrıcalıklıdır ve bu onları dikkat çekici yapar ve bu yüzden daha çok akran etkisine yatkındır.

\section{Özel olarak tüketilen lüks ürünler:}

Tüketimi esnasında başkaları tarafından gözlemlenmeyen ve yaygın olarak sahip olunamayan veya kullanılamayan ürünlerdir. Bu ürünler yüksek akran etkisine sahiptirler çünkü bunlar önemlidirler ve daha keyfi satın alımlardır.

\section{Halka açık olarak (kamusal) tüketilen gereksinim maddeleri:}

Tüketilirken gözlemlenen ve yaygın olarak sahip olunan ürünlerdir. Bu ürünün satın alınması kararı muhtemelen düşük düzeyde akran etkisi çeker çünkü hemen hemen herkes bu ürüne sahiptir.

\section{Özel olarak tüketilen gereksinim maddeleri:}

Toplumun görüşü dışında tüketildiği ve herkes tarafından kullanıldığı için gözlemlenemeyen ve seçkin olmayan ürünlerdir. Bu tür ürünler ve markalar toplumsal açıdan önemli değildir ve bu yüzden akranlar tarafından etkilenme intimali yoktur.

Kaynak: Makgosa ve Mohube, 2007, s. 66.

Bu çalışmada kullanılması amaçlanan ürünleri değerlendirmek için öncelikli olarak bir anket oluşturulmuştur. Bu araştırmada 12 ürün kullanıımıştır. Bu 12 ürün Bearden ve Etzel (1982), Childers ve Rao (1992) ve Makgosa ve Mohube (2007) tarafından yapılan çalışmalardan derlenerek sorulmuştur. Seçilen ürünler Türkiye piyasasında ticari olarak bulunan üniversite öğrencileri arasında yaygın olarak algılanan ve öğrencilerin onları satın alabilmeleri ölçüsüne dayanarak seçilmiştir. Bu nedenle, kıyafet, deodorant, temizlik malzemesi, gezi, kol saati, cep telefonu, ayakkabı, bilgisayar, diş macunu, güneş gözlüğü, gıda, fotoğraf makinesi içeren 12 ürün seçilmiştir.

Katılımcılardan, kamusal lüksü, kamusal gerekliliği, özel lüksü ve özel gerekliliği kapsayacak biçimde her bir kategoriye ait üçer ürün seçilmesi istenmiştir. Bu nedenle, her bir katılımcı üç farklı ürün hakkındaki tercihlerine ilişkin cevaplarını sunmuşlardır. Üniversite öğrencilerinin, kendi görüşlerini bu on iki ürünün lüks veya gereklilik olduğunu $1=$ herkes için bir lüks'den $6=$ herkes için bir gereklilik'e kadar uzanan altı puanlı bir ölçekle belirtmeleri istenmiştir. Ürünlerin genel olarak mı yoksa özel olarak mı tüketildiğinin algılandığını değerlendirmek için $1=$ herkes için genel (kamusal) bir ürün'den $6=$ herkes için özel bir ürün'e kadar uzanan altı puanlı bir ölçek kullanılmıştır. Bu ölçekler Bearden ve Etzel (1982)'den uyarlanmıştır.

12 ürün için hesaplanan ortalama puanlara dayanarak, ürünler aşağıdaki kategorilerde sınıflandırımışlardır. Kıyafet, gıda, ayakkabı, kamusal gereklilik (n: 107); deodorant, diş macunu temizlik malzemesi, özel gereklilik (n: 101); 
gezi, güneş gözlüğü, kol saati, kamusal lüksler (n: 98); cep telefonu, bilgisayar, fotoğraf makinesi, özel lüksler (n: 100) kategorisine konmuştur.

Ürün kategorileri belirlendikten sonra araştırmanın hipotezleri, referans gruplarının satın alma kararları etkisini belirleyecek düzeyde 12 hipotez şeklinde oluşturulmuştur. Hipotezler Bearden ve Etzel (1982), Childers ve Rao (1992) ve Makgosa ve Mohube (2007) tarafından belirlenen hipotezlere tutarlı olarak özetlenmiştir.

$\mathbf{H}_{\mathbf{1}}$ : Referans gruplarının bilgilendirici etkisi açısından, kamusal lüks (KL) ve kamusal gerekli (KG) ürünlerin satın alınmalarında anlamlı fark vardır.

$\mathbf{H}_{\mathbf{2}}$ : Referans gruplarının bilgilendirici etkisi açısından, kamusal lüks (KL) ve özel gerekli (ÖG) ürünlerin satın alınmalarında anlamlı fark vardır.

$\mathbf{H}_{\mathbf{3}}$ : Referans gruplarının bilgilendirici etkisi açısından, özel lüks (ÖL) ve kamusal lüks $(K L)$ ürünlerin satın alınmalarında anlamlı fark vardır.

$\mathbf{H}_{4}$ : Referans gruplarının bilgilendirici etkisi açısından, özel gerekli (ÖG) ve kamusal gerekli (KG) ürünlerin satın alınmalarında anlamlı fark vardır.

$\mathbf{H}_{\mathbf{5}}$ : Referans gruplarının bilgilendirici etkisi açısından, özel lüks (ÖL) ve kamusal gerekli (KG) ürünlerin satın alınmalarında anlamlı fark vardır.

$\mathbf{H}_{\mathbf{6}}$ : Referans gruplarının bilgilendirici etkisi açısından, özel lüks (ÖL) ve özel gerekli (ÖG) ürünlerin satın alınmalarında anlamlı fark vardır.

$\mathbf{H}_{7}$ : Referans gruplarının normatif etkisi açısından, kamusal lüks (KL) ve kamusal gerekli (KG) ürünlerin satın alınmalarında anlamlı fark vardır.

$\mathbf{H}_{\mathbf{8}}$ : Referans gruplarının normatif etkisi açısından, kamusal lüks (KL) ve özel gerekli (ÖG) ürünlerin satın alınmalarında anlamlı fark vardır.

$\mathbf{H}_{\mathbf{g}}$ : Referans gruplarının normatif etkisi açısından, özel lüks (ÖL) ve kamusal lüks (KL) ürünlerin satın alınmalarında anlamlı fark vardır.

$\mathbf{H}_{\mathbf{1 0}}$ : Referans gruplarının normatif etkisi açısından, özel gerekli (ÖG) ve kamusal gerekli (KG) ürünlerin satın alınmalarında anlamlı fark vardır.

$\mathbf{H}_{\mathbf{1 1}}$ : Referans gruplarının normatif etkisi açısından, özel lüks (ÖL) ve kamusal gerekli (KG) ürünlerin satın alınmalarında anlamlı fark vardır.

$\mathbf{H}_{\mathbf{1 2}}$ : Referans gruplarının normatif etkisi açısından, özel lüks (ÖL) ve özel gerekli (ÖG) ürünlerin satın alınmalarında anlamlı fark vardır.

Araştırmada asıl olarak iki temel değişken kullanılmaktadır. Bunlardan referans gruplarının bilgilendirici ve normatif etkisi bağımsız (tahmin) değişken, satın alma kararları ise bağımlı (karar) değişken olarak ele alınmaktadır. Satın alma kararlarının alt bileşenleri, kamusal gerekli ürünler, kamusal lüks olarak algılanan ürünler, özel gerekli olan ürünler ve özel lüks olarak belirlenen ürünlerin satın alınması ve tüketilmesidir. Referans gruplarının alt bileşenleri ise ait olunan arkadaş gruplarıdır. 


\section{Araştırma Yöntemi}

Araştırmanın anket formu hazırlanarak katılımcılardan alınan cevaplarla hipotez testleri analiz edilmek istenmiştir. Anket formu, iki bölümden oluşmakta olup, birinci bölüm cevaplayıcıların demografik özelliklerine ilişkin soruları kapsamaktadır. İkinci bölüm cevaplayıcıların kamusal gerekli kabul edilen ürünler, kamusal lüks olarak algılanan ürünler, özel gerekli olan ürünler ve özel lüks olarak belirlenen ürünlerin satın alınmasında referans gruplarından bilgilendirici ve normatif etkilenme düzeyinin belirlenmesine yönelik sorular içermektedir. Bu bölümde yer alan sorularda beşli Likert Ölçeği (1: Tamamen Katılıyorum, 2: Katılıyorum, 3: Kararsızım, 4: Katılmıyorum, 5: Tamamen Katılmıyorum) kullanılmıştır.

Anket soruları tek seçenekli ve kapalı sonlu sorulardan oluşmaktadır.

Ayrıca demografik faktörde yer alan bir arkadaş grubu olmayan katılımcıların anketi sonlandırılması istenmiştir. Toplam 500 anket bastırılmış ve uygulanmıştır. Bu anketlerden 91'i eksik ve hatalı doldurulduğundan, 13 ankette ise, bir arkadaş grubunun bulunmadığı (ankete devam etmeyen katılımcıların demografik ifadeleri analize dâhil edilmemiştir) ifade edildiğinden, 396 anket değerlendirmeye alınmıştır. Araştırma verileri 11 Ocak-31 Ocak 2016 tarihleri arasında toplanmıştır.

Anket formunda bulunan sorulara öğrencilerin verdikleri cevaplar, SPSS 20.0 paket programı kullanılarak analiz edilmiştir. Anket formunun doğruluğunu test etmek, gerekli düzenleme ve düzeltmeleri yapmak amacıyla örneklem ile benzer özellikler taşıyan 45 kişilik bir gruba pilot araştırma kapsamında anket formu uygulanmış ve daha sonra anket formuna son şekli verilmiştir.

Araştırmanın istatistiksel güvenilirliği, Cronbach Alpha yöntemi ile sınanmıştır. Anketteki maddeler arasındaki iç tutarlıı̆̆ı belirlemek amacıyla güvenirlik katsayısı hesaplanmıştır.

Bu ilk uygulama sonucunda Cronbach's Alpha; 0.93 olarak tespit edilmiş bu oran ölçeğin yüksek derecede güvenilir olduğunu gösterdiğinden anket uygulamasına devam edilmiştir.

Araştırma verilerinin analizinde öğrencilerin demografik özelliklerini değerlemede tanımlayıcı istatistik bulgulara yer verilmektedir. Araştırmaya katılan öğrencilerin satın alma kararlarının referans gruplarından etkilenme durumunun ürün özelliklerine göre farklılık gösterip göstermediği faktör analizi ve t testi analizi ile ortaya konulmaktadır. 


\section{Ana Kütle ve Örneklem}

Ana kütleyi oluşturan Süleyman Demirel Üniversitesi, 2015-2016 eğitim öğretim yılı sonu itibariyle 19 fakülte, 21 meslek yüksekokulu, 6 enstitü ve 4 yüksekokul bünyesinde 47724 öğrenciye ulaşmış bulunmaktadır. Bu öğrencilerden 25575'i lisans öğrencisi, 18504'ü önlisans öğrencisi ve yüksek lisans ve doktora öğrenimi gören öğrenci sayısı ise 3645 kişidir (www.sdu.edu.tr). Öğrenci sayısı ile nüfus oranlandığında Isparta nüfusunun her 8,8 kişiden 1'i Süleyman Demirel Üniversitesi öğrencisidir. Nüfusun \%11,3'ü üniversite öğrencisinden oluşması Isparta'nın bir üniversite şehri olduğunu göstermektedir. Süleyman Demirel Üniversitesi'nin kent ekonomisine katkılarını öğrenci harcamaları bağlamında analiz eden bir çalışmanın sonuçlarına göre; üniversite öğrencilerinin yapmış oldukları harcamalar, kent ekonomisi için çok önemli bir talep kaynağıdır. Araştırmanın sonuçlarına göre; Süleyman Demirel Üniversitesi'nde öğrenim gören bir öğrencinin aylık ortalama harcaması 2009 yılı rakamlarına göre yaklaşık 474 TL'dir. Yine 2009 rakamlarına göre öğrenci harcamalarının Isparta ekonomisine toplam katkısı yıllık 80 milyon TL'yi aşmaktadır. 2009 yılında Isparta'nın ihracat rakamının 120 milyon \$ olduğu düşünülürse öğrencilerin kent ekonomisine yaptıkları katkı hiç de azımsanmayacak bir düzeydedir. (Akçakanat vd. , 2010, s. 176).

Isparta ili ekonomisinin oldukça büyük bir bölümü doğrudan ya da dolaylı olarak üniversiteye bağımlıdır. Bu çalışmada, Süleyman Demirel Üniversitesi öğrencileri, Isparta iline yaptıkları ekonomik katkı göz önünde bulundurularak ana kütle olarak ele alınmıştır.

Bu bağlamda üniversite öğrencilerinden anket yoluyla veri toplanmıştır. Araştırmada zaman ve maliyet kısıtları, iş yoğunluğu sebebiyle tesadüfü olmayan örnekleme yöntemi uygulanmış ve cevaplayıcılar kolayda örnekleme yöntemiyle seçilmiştir.

Evren büyüklüğü belli ise, örneklem büyüklüğünün hesabı şu formülle hesaplanmıstır (Balcı, 2001, s. 107):

$n=Z^{2} \pi(1-\pi) N / Z^{2} \pi(1-\pi)+(p-\pi)^{2}(N-1)$

$n$ : Örnekleme alınacak birey sayısı

Z: Güven düzeyine göre standart değer. Normal dağılım tablolarından bulunur. \%95 için, 1,96

$\pi$ : Evren içinde ilgilendiğimiz özellikteki birimlerin oranı. Bu rakam 0,50 olarak alınır

p: Örnek içinde ilgilendiğimiz özellikteki birimlerin oranı

$\mathrm{N}$ : Hedef kitledeki birey sayısı

p- $\pi$ : Göz yumulabilir yanılgı (\%5)

$n=1,96^{2} \cdot 0,50 \cdot(1-0,50) .47724 / 1,96^{2} \cdot 0,50 \cdot(1-0,50)+(0,05)^{2} \cdot 47723$

$n=382$ 


\section{Verilerin Analizi}

\section{Demografik Özellikler}

Katılımcıların demografik özelliklerine ait bulgular Tablo 2.'de yer almaktadır.

Tablo 2. Katılımcıların Demografik Özellikleri

\begin{tabular}{|llllll|}
\hline $\begin{array}{l}\text { Demografik } \\
\text { Özellikler }\end{array}$ & Frekans & Yüzde & $\begin{array}{l}\text { Demografik } \\
\text { Özellikler }\end{array}$ & Frekans & Yüzde \\
\hline Cinsiyet & & & $\begin{array}{l}\text { Kulüp, Dernek } \\
\text { Üyelik }\end{array}$ & & \\
\hline Kadın & 225 & 56,8 & Evet & 95 & 24,0 \\
\hline Erkek & 171 & 43,2 & Hayır & 301 & 76,0 \\
\hline Yaş & & & $\begin{array}{l}\text { Öğrencilik } \\
\text { Durumu }\end{array}$ & & \\
\hline $17-20$ & 131 & 33,1 & Önlisans & 194 & 49,0 \\
\hline $21-24$ & 233 & 58,8 & Lisans & 148 & 37,4 \\
\hline $24-27$ & 19 & 4,8 & Lisans Üstü & 54 & 13,6 \\
\hline $27-30$ & 9 & 2,3 & & & \\
\hline 30 üstü & 4 & 1,0 & & & \\
\hline
\end{tabular}

Ankete katılan öğrencilerin cinsiyete göre dağılımı incelendiğinde (Tablo 2.) katılımcıların \%56,8'inin kadın, \%43,2'sinin erkek olduğu görülmektedir. Katıımcıların \%33,1'i 17-20yaş arasındaki grupta yer alırken, \%58,8'i 21-24 yaş grubunda, \%4,8'i 24-27 yaş grubunda, \%2,3'ü 27-30 yaş grubunda ve \% 1'i ise 30 yaş üzeri grubunda yer almaktadır.

Tablo 2.'ye göre katılımcıların \%24'ü herhangi bir kulübe, derneğe vs üye olduklarını, \%76'sı ise herhangi bir üyeliklerinin bulunmadığını belirtmiştir.

Katılımcıların şuan ki öğrencilik durumu sorulduğunda ise, \%49'u önlisans, \%37,4'ü lisans, \%13,6'sı ise lisansüstü öğrencisi olduklarını ifade etmişlerdir.

\section{Hipotez Testleri}

Araştırmada katıımcıların ürün satın alma kararlarında referans gruplarından etkilenme boyutunu belirlemeye yönelik ifadeler kendi aralarında gruplandırılarak faktör analizine tabi tutulmuştur.

Araştırmada, katııımcıarın ürün satın alma kararlarında referans gruplarının etkisi bilgilendirici ve normatif olarak iki boyutta faktör analizi kullanılarak kısıtlanmıştır. Faktörler Tablo 3.'de sunulmuştur. 
Tablo 3. Referans gruplarının Satın Alma Kararlarına Olan Etkilerini Belirlemeye Yönelik Ifadelerin Toplam Varyans Analizleri

\begin{tabular}{|c|c|c|}
\hline \multirow{2}{*}{ Faktör 1: Normatif Etki } & \multirow{2}{*}{$\begin{array}{l}\text { Faktör } \\
\text { Yükleme }\end{array}$} & \%varyans \\
\hline & & 52,249 \\
\hline $\begin{array}{l}\text { Kamusal gerekli ürünleri (kıyafet, gıda, ayakkabı) satın alırken arkadaşla- } \\
\text { rımdan onay alıım }\end{array}$ & .819 & \\
\hline $\begin{array}{l}\text { Aldığım özel gerekli ürünlerden (deodorant, diş macunu temizlik malze- } \\
\text { mesi) arkadaşlarımın hoşlanması önemlidir }\end{array}$ &, 816 & \\
\hline $\begin{array}{l}\text { Doğru kamusal gerekli ürünü (kıyafet, gıda, ayakkabı) aldığımdan emin } \\
\text { olmak için, genellikle arkadaşlarımın ne aldığını ve kullandığını gözlem- } \\
\text { lerim }\end{array}$ &, 768 & \\
\hline $\begin{array}{l}\text { Aldığım kamusal gerekli ürünlerden (kıyafet, gıda, ayakkabı) arkadaşları- } \\
\text { mın hoşlanması önemlidir }\end{array}$ & .766 & \\
\hline $\begin{array}{l}\text { Özel gerekli ürünleri (deodorant, diş macunu temizlik malzemesi) satın } \\
\text { alırken arkadaşlarımdan onay alııım }\end{array}$ & ,737 & \\
\hline $\begin{array}{l}\text { Kamusal lüks ürünleri (gezi, güneş gözlüğü, kol saati) satın alırken } \\
\text { arkadaşlarımdan onay alıım }\end{array}$ & .721 & \\
\hline $\begin{array}{l}\text { Doğru özel gerekli ürünleri (deodorant, diş macunu temizlik malzemesi) } \\
\text { aldığımdan emin olmak için, genellikle arkadaşlarımın ne aldığını ve } \\
\text { kullandığını gözlemlerim }\end{array}$ & 693 & \\
\hline $\begin{array}{l}\text { Özel lüks ürünleri (cep telefonu, bilgisayar, fotoğraf makinesi) satın } \\
\text { alırken arkadaşlarımdan onay alıım }\end{array}$ & ,692 & \\
\hline $\begin{array}{l}\text { Doğru kamusal lüks ürünleri (gezi, güneş gözlüğü, kol saati) aldığımdan } \\
\text { emin olmak için, genellikle arkadaşlarımın ne aldığını ve kullandığını } \\
\text { gözlemlerim }\end{array}$ & .676 & \\
\hline $\begin{array}{l}\text { Aldığım kamusal lüks ürünlerden (gezi, güneş gözlüğü, kol saati) arka- } \\
\text { daşlarımın hoşlanması önemlidir }\end{array}$ & 643, & \\
\hline $\begin{array}{l}\text { Aldığım özel lüks ürünlerden (cep telefonu, bilgisayar, fotoğraf makine- } \\
\text { si) arkadaşlarımın hoşlanması önemlidir }\end{array}$ & & \\
\hline $\begin{array}{l}\text { Doğru özel lüks ürünleri (cep telefonu, bilgisayar, fotoğraf makinesi) } \\
\text { aldığımdan emin olmak için, genellikle arkadaşlarımın ne aldığını ve } \\
\text { kullandığını gözlemlerim }\end{array}$ & & \\
\hline
\end{tabular}




\begin{tabular}{|c|c|c|}
\hline Faktör 2: Bilgilendirici etki & & 16,932 \\
\hline $\begin{array}{l}\text { Özel lüks ürünleri (cep telefonu, bilgisayar, fotoğraf makinesi) almadan } \\
\text { önce, o ürün hakkında arkadaşlarımdan bilgi toplarım } \\
\text { Kamusal gerekli ürünlerden (kıyafet, gıda, ayakkabı) en iyi alternatifi } \\
\text { seçmeme yardım etmeleri için genellikle diğer arkadaşlarıma danışıım } \\
\text { Özel gerekli ürünlerden (deodorant, diş macunu temizlik malzemesi) } \\
\text { en iyi alternatifi seçmeme yardım etmeleri için genellikle diğer } \\
\text { arkadaşlarıma danı̧ııım } \\
\text { Kamusal lüks ürünleri (gezi, güneş gözlüğü, kol saati) almadan önce, o } \\
\text { ürün hakkında arkadaşlarımdan bilgi toplarım } \\
\text { Özel gerekli ürünleri (deodorant, diş macunu temizlik malzemesi) } \\
\text { almadan önce, o ürün hakkında arkadaşlarımdan bilgi toplarım } \\
\text { Kamusal gerekli ürünleri (kıyafet, gıda, ayakkabı) almadan önce, o ürün } \\
\text { hakkında arkadaşlarımdan bilgi toplarım } \\
\text { Kamusal lüks ürünlerden (gezi, güneş gözlüğü, kol saati) en iyi alter- } \\
\text { natifi seçmeme yardım etmeleri için genellikle diğer arkadaşlarıma } \\
\text { danışıım } \\
\text { Özel lüks ürünlerden (cep telefonu, bilgisayar, fotoğraf makinesi) en iyi } \\
\text { alternatifi seçmeme yardım etmeleri için genellikle diğer arkadaşlarıma } \\
\text { danışııım }\end{array}$ & $\begin{array}{l}.849 \\
.740 \\
.710 \\
.702 \\
.667 \\
.627 \\
.610 \\
.564\end{array}$ & \\
\hline
\end{tabular}

Bu çalışmayı gerçekleştirmek amacıyla, ürünlerde referans grubu etkisini belirlemek için yapılan Faktör Analizinde, toplam açıklanan varyansın \%69,181'ine katkıda bulunan iki faktörü kapsadığı belirlenmiştir.

Faktör 1 (Normatif etki): Başkalarının pozitif beklentileri ile uyumlu olma eğilimindedir. Görünüm ve sosyal statü normatif etkinin en önemli belirleyici faktörleridir.

Faktör 2 (Bilgilendirici etki): Bilgilendirici etkinin en önemli belirleyici faktörleri mesaj içeriği, kaynak güvenilirliğidir.

Faktör analizi sonucu ortaya çıkan iki faktör (Normatif ve Bilgilendirici etki) ile ürün kategorileri arasındaki ilişki ve farklılıklar belirlenmiş hipotezler doğrultusunda "T Testi" ile test edilmiştir (Tablo 4.).

Tablo 4. Hipotezlerin ve Sonuçların İkili Karşılaştırması

\begin{tabular}{|c|c|c|c|c|c|}
\hline \multirow[t]{2}{*}{ Hipotezler } & \multirow{2}{*}{$\begin{array}{l}\text { Bilgilendirici } \\
\text { etki } \\
\text { Ort. }\end{array}$} & \multirow[t]{2}{*}{$\begin{array}{l}\text { Sig. } \\
\text { (2-tailed) }\end{array}$} & \multirow[t]{2}{*}{ Hipotezler } & \multirow{2}{*}{\begin{tabular}{|l|}
$\begin{array}{l}\text { Normatif } \\
\text { etki }\end{array}$ \\
Ort. \\
\end{tabular}} & \multirow[t]{2}{*}{$\begin{array}{l}\text { Sig. } \\
\text { (2-tailed) }\end{array}$} \\
\hline & & & & & \\
\hline $\begin{array}{l}\mathrm{H}_{1} \text { : Kamusal } \\
\text { Lüks - Kamusal } \\
\text { Gereklilik }\end{array}$ & $2,78-3,05$ &, 025 & $\begin{array}{l}\mathrm{H}_{7}: \text { Kamusal } \\
\text { Lüks - Kamusal } \\
\text { Gereklilik }\end{array}$ & $2,63-2,67$ & ,668 \\
\hline $\begin{array}{l}\mathrm{H}_{2} \text { : Kamusal Lüks } \\
\text { - Ozel Gereklilik }\end{array}$ & $2,78-3,29$ & ,000 & \begin{tabular}{|l}
$\mathrm{H}_{8}:$ Kamusal Lüks \\
- Ozel Gereklilik \\
\end{tabular} & $2,63-2,70$ & ,384 \\
\hline $\begin{array}{l}\mathrm{H}_{3} \text { : Özel Lüks - } \\
\text { Kamusal Lüks }\end{array}$ & $2,71-2,78$ & ,315 & $\begin{array}{l}\mathrm{Hg} \text { : Özel Lüks - } \\
\text { Kamusal Lüks } \\
\end{array}$ & $2,58-2,63$ & ,331 \\
\hline
\end{tabular}




\begin{tabular}{|l|l|l|l|l|l|}
\hline $\begin{array}{l}\mathrm{H}_{4}: \text { Özel Ger- } \\
\text { eklilik - Kamusal } \\
\text { Gereklilik }\end{array}$ & $3,29-3,05$ &, 042 & $\begin{array}{l}\mathrm{H}_{10} \text { : Özel Ger- } \\
\text { eklilik - Kamusal } \\
\text { Gereklilik }\end{array}$ & $2,70-2,67$ &, 712 \\
\hline $\begin{array}{l}\mathrm{H}_{5}: \text { Özel Lüks - } \\
\text { Kamusal Gereklilik }\end{array}$ & $2,71-3,05$ &, 000 & $\begin{array}{l}\mathrm{H}_{11}: \text { Özel } \\
\text { Lüks - Kamusal } \\
\text { Gereklilik }\end{array}$ & $2,58-2,67$ &, 039 \\
\hline $\begin{array}{l}\mathrm{H}_{6} \text { : Özel Lüks - } \\
\text { Özel Gereklilik }\end{array}$ & $2,71-3,29$ &, 000 & $\begin{array}{l}\mathrm{H}_{12}: \text { Özel Lüks - } \\
\text { Ozzel Gereklilik }\end{array}$ & $2,58-2,70$ &, 000 \\
\hline
\end{tabular}

Not: $n=396,1$ : kesinlikle katılıorum, 5: kesinlikle katımıyorum anlamındadır.

T testi sonuçları, ortalamalar dikkate alındığında referans gruplarının ürün satın alma kararlarında normatif ve bilgilendirici etkilerinin olduğunu, ürünler arasında ise normatif ve bilgilendirici etkilerin değiştiğini göstermektedir. Buna göre referans gruplarının kamusal lüks ve kamusal gerekli ürünlerde, bilgilendirici ve normatif etkilerin farklı olduğu ifade edilen hipotezlerin $\left(\mathrm{H}_{1}, \mathrm{H}_{7}\right)$, tablo 4.'deki sonuçları, \%5 önem değeri (Sig. (2-tailed))'ne göre $\mathrm{H}_{1}$ 'i desteklemekte, $\mathrm{H}_{7}$ 'yi reddetmektedir. Yani, kamusal lüks ürünlerin satın alınmasında kamusal gerekli ürünlere göre referans gruplarının bilgilendirici etkisi daha fazladır $\left(\mathrm{H}_{1}\right)$. Bu ürünler arasında normatif etki açısından ise anlamlı bir fark yoktur $\left(\mathrm{H}_{7}\right)$.

Yapılan analiz sonucunda \%5 önem değeri (Sig. (2-tailed))'ne göre $\mathrm{H}_{2}$ kabul edilmiş, $H_{8}$ reddedilmiştir. Kamusal lüks olarak tüketilen ürünün satın alınmasında bilgilendirici etkinin özel gerekli olan ürüne göre daha fazla olduğu ortaya çıkmıştır $\left(\mathrm{H}_{2}\right)$ Bu ürünler arasında normatif etki açısından anlamlı bir fark yoktur $\left(\mathrm{H}_{8}\right)$.

Bilgilendirici ve normatif etkinin, lüks faktörünün onları özel ve dikkat çekici yapmasından dolayı, kamusal ve özel tüketilen lüks ürünlerin satın alınmasında bilgilendirici ve normatif etkiler açısından bir fark yoktur. $\mathrm{H}_{3}$ ve $\mathrm{H}_{9}$ hipotezleri reddedilmiştir. Ancak referans gruplarının bu iki ürün için normatif ve bilgilendirici etkisi diğer ürünlere göre daha yüksek olduğu tespit edilmiştir.

Tablo 4.'teki analiz sonuçları, \%5 önem değeri (Sig. (2-tailed))'ne göre $\mathrm{H}_{4}$ 'ü desteklemekte, $\mathrm{H}_{10}$ 'u reddetmektedir. Yani, kamusal gerekli ürünlerin satın alınmasında özel gerekli ürünlere göre referans gruplarının bilgilendirici etkisinin daha yüksek olduğu tespit edilmiştir $\left(\mathrm{H}_{4}\right)$. Bu ürünler arasında normatif etki açısından anlamlı bir fark bulunmamıştır $\left(\mathrm{H}_{10}\right)$.

$\mathrm{H}_{5}$ ve $\mathrm{H}_{11}$ hipotezlerinin test edilmesinde, özel lüks olan ürünlerin satın alınmasında, kamusal gerekli olan ürünler açısından \%5 önem değeri (Sig. (2-tailed))'ne göre bilgilendirici ve normatif etkilerinin fazla olduğu belirlenmiştir.

Özel lüks ve özel gerekli ürünler üzerindeki bilgilendirici ve normatif etkilerin test edildiği $\mathrm{H}_{6}$ ve $\mathrm{H}_{12}$ hipotezlerden her iki hipotezde \%5 önem değeri (Sig. (2-tailed))'ne göre kabul edilmiştir. Buna göre, özel lüks ürünlerin 
satın alınmasında özel gerekli ürünlere göre bilgilendirici ve normatif etkinin daha yüksek olduğu tespit edilmiştir.

\section{Değerlendirme ve Sonuç}

Isparta'da bulunan üniversite öğrencileri üzerine yapılan bu çalışma, mevcut literatüre paralel olarak, referans gruplarının bireyin satın alma kararlarında bilgilendirici ve normatif etkisi olduğunu ortaya çıkarmıştır. Ancak mevcut durumunun ürün kategorisi kapsamında farklı etkilenme düzeylerine sahip olduğu belirlenmiştir.

Çalışmada, ürünler arasında yapılan karşılaştırmalı sonuçlara göre, kamusal lüks ürünlerin satın alınmasında, kamusal gerekli ve özel gerekli olan ürüne göre referans gruplarının bilgilendirici etkisinin daha fazla olduğu tespit edilmiştir. Bunun nedeni, lüks ürünlerin gereklilerden farklı olarak herkes tarafından sahip olunamadığı ve bu yüzden nispeten daha fazla dikkat çekici olması şeklinde değerlendirilebilir. Aynı zamanda kamusal olarak tüketilen ürünler özel olarak tüketilen ürünlere oranla tüketiciler tarafından daha kolay fark edilebilir ürünlerdir. Örneğin, yelkenli/yat gibi bir kamusal lüks ürünü satın almayı düşünen bir kişi, başkaları tarafından güçlü bir şekilde etkilenebilir. Çok az kişi yelkenli ya da yata sahip olduğu için çok kişinin dikkatini çekecektir. Ürün herkesin önünde tüketildiği için de kamuoyu, ürünün (yat veya yelkenli) markasına da dikkat edecektir. Dolayısıyla bu örnekte hem ürün hem marka göstermelik (dikkat çekici) olacaktır. Bu nedenle de bir yelkenliye sahibi olup olmama ve hangi markaya sahip olma konusunda başkalarının fikirleri tüketicinin kararını etkileyebilecektir (Armstrong'dan aktaran Tek, 1997, s. 202). Kulviwat ve diğerleri (2009, s. 706) tarafından, yüksek teknoloji yeniliklerinin kabul edilmesinde sosyal çevrenin rolünün araştııılığı çalışmada da, sosyal çevrenin ileri teknoloji yeniliklerini benimsemesinde etkisinin, özel tüketim ürünlerinden ziyade kamusal tüketim ürünlerinde, daha güçlü olduğu tespit edilmiştir.

Çalışmada, kamusal gerekli ürünlerin satın alınmasında özel gerekli ürünlere göre referans gruplarının bilgilendirici etkisinin daha yüksek olduğu belirlenmiştir. Özel lüks olan ürünlerin satın alınmasında ise, kamusal gerekli ve özel gerekli ürünler açısından bilgilendirici ve normatif etkinin yüksek olduğu belirlenmiştir. Örneğin, çarşaf gibi özel gerekli bir tüketim ürünün alımında, genelde ve birçok kültürde, ülkede, ne marka ne de ürün başkalarının dikkatini çekebilecektir (Armstrong'dan aktaran Tek, 1997, s. 202). Dolayısıyla, ürünün dikkat çekiciliği, o ürünün satın alınması konusunda bireyin gruptan etkilenme olasııı̆ını düşürmektedir (Eze vd., 2012, s. 64)

Ayrıca, lüks olarak tüketilen kamusal ve özel ürünlerin satın alınmasında referans gruplarının bilgilendirici ve normatif etkisinin olduğu, ancak ürünler arasında bir fark olmadığı yapılan çalışmada ortaya çıkmıştır. Buna göre, genç yetişkinlerin lüks ürünleri satın alırken diğer ürünlere göre daha fazla bilgilendirici 
etkiye maruz kaldıkları literatüre paralel bir yapıda ortaya çıkmıştır. Normatif etkinin en çok hissedildiği özel lüks ürünlerin satın alınmasında ise yapılan çalışmalarda elde edilen sonuçlarla benzerlik söz konusudur. Genel olarak, mevcut çalışmanın sonuçları önceki diğer çalışmalarda elde edilen sonuçlarla örtüşmektedirler.

Bearden ve Etzel (1982), Childers ve Rao (1992) ve Makgosa ve Mohube (2007) tarafından yürütülen çalışmalar temel alınarak ele aldığımız bu çalışma, yapılan diğer çalışmalarla karşılaştıııldığında, Bearden ve Etzel (1982) tarafından yapılan çalışma sonucunda, normatif etkiler önemli olmazken, bilgilendirici etkinin kamusal ve özel tüketilen lüks ürünler üzerinde; kamusal tüketilen gerekli ürünler üzerinde olandan daha büyük olduğu tespit edilmiştir. Bu bulgu bizim çalışma sonucunda ulaştığımız bulguyla paraleldir. Ancak kamusal olarak tüketilen lüks ürünlerin, özel olarak tüketilen lüks ürünlerden daha fazla bilgilendirici ve normatif etkisinin olması Bearden ve Etzel (1982) tarafından yapılan çalışmadaki sonuçlara göre farklı olduğunu göstermiştir.

Childers ve Rao (1992) tarafından yapılan çalışmada kamusal ve özel olarak tüketilen lüks ürünler, kamusal olarak tüketilen gereksinim maddelerinden daha güçlü bir akran etkisi olmadığı yönündedir. Ayrıca kamusal olarak tüketilen gereksinim maddelerinin satın alınması üzerinde özel olarak tüketilen gereksinim maddelerin satın alınması üzerinde olandan daha güçlü bir akran etkisi bulunmuştur. Üniversite öğrencileri arasında gerçekleştirmiş olduğumuz bu çalışmada ise, ürün kategorisi kapsamında elde ettiğimiz bulgular, geçmişte Childers ve Rao (1992) tarafından yapılan çalışmaya göre tam tersi yönünde bir sonuç ortaya çıktığını göstermiştir.

Makgosa ve Mohube (2007) tarafından yapılan çalışmaya göre ise, özel bir lüks ve özel gerekli bir ürünün kamusal bir lüks için daha fazla normatif etkisi olduğu belirlenmiştir. Bilgi etkisi, kamusal bir gereklilikten özel bir lüks için daha fazla olmuştur. Bu bulgu, bizim çalışmamızda ulaştığımız bulguyu destekler niteliktedir. Ancak, kamusal ve özel gerekli üründe diğer ürünlere göre daha yüksek bir bilgilendirici ve normatif olduğu yaptığımız çalışmada desteklenmemiştir.

Çalışma sonuçlarına göre, gözlemlenen ürünler için üniversite öğrencilerinin arkadaş gruplarının beklentilerine uyma eğiliminde oldukları ve aynı zamanda ürünün özel veya yaygın olarak sahip olunup olunmadığın bakılmaksızın bu gruplardan bilgi alarak bilgilendirilmiş kararlar verdikleri tespit edilmiştir. Normatif etki açısından ise, öğrencilerin ürün satın alırken, arkadaş gruplarının pozitif beklentilerine uygun davranma eğilimi içerisinde bulundukları belirlenmiştir. Mangleburg ve diğerleri (2004, s. 101) tarafından yapılan özellikle, ürün/hizmet satın alma davranışı üzerinde, arkadaşların bilgilendirici ve normatif etkilerinin tespit edildiği çalışma sonuçları da mevcut bulgumuzu destekleyecek niteliktedir. Çalışmamızda özellikle, özel lüks olarak tüketilen ürünlerde bu etkinin daha fazla olduğu ortaya çıkmıştır. Bu durum öğrencilerin, herkesin sahip olmadığı ve önemli 
olan ürünlerin satın alma kararlarını verirken, tüketildiğinde ayrıcalıklı olma hissinin ortaya çıkabileceği düşünülerek daha fazla arkadaş gruplarının beklentilerine uymak üzere motive olduklarını ortaya koyabilir.

Sonuç olarak, lüks ürünlerin satın alınmasında arkadaş gruplarına danışılarak onlardan bilgi alarak (nereden satın alınacağı, nasıl kullanılacağı, tavsiyeler, fiyat karşılaştırmaları, ...vb.) gerçekleştirme eğilimi (bilgilendirici etki) diğer ürünlere göre daha fazladır. Normatif etki (arkadaş grubunun ürünü beğenmesi, pozitif yönde olumlu mesajlar sunması, grup içerisinde ürünün fark edilmesi, göze çarpması vb.) açısından ise, özel olarak tüketilen lüks ürünlerin diğer ürünlere göre daha fazla birey üzerinde etkiye sahip olduğu ifade edilebilir.

Bu araştırma üniversite öğrencileri tarafından tüketilen çeşitli ürünlerin arasında referans grupları etkisinin nasıl değişebileceği konusundaki değerlendirmemize katkıda bulunmaktadır. Bu çalışmanın tasarımı pazarlama kampanyalarına veya genç yetişkin tüketicileri hedef pazar olarak seçen pazarlamacılara referans olabileceği düşünülmektedir. Dolayısıyla bu çalışma, pazarlamacıların hedef pazar belirlemede, ürün satışlarındaki tutundurma çalışmalarında referans gruplarını göz önüne alarak kullanabilecekleri bir çerçeve sunmaktadır. Özellikle, bu çalışmanın bulgularına dayanarak, bilgilendirici ve normatif etkinin ürün seçimlerinde farklı sonuçları olduğu dolayısıyla bunların bağlantılarının dikkate alınması gerektiği ifade edilebilir.

Reklam kampanyalarında, arkadaş gruplarının ürün onaylamalarında uzman olarak kullanarak, bilgi verici etkiye vurgu yapılabilir. Reklam kampanyalarında normatif etki ise, belirli ürünlerin kullanımının genç yetişkin tüketicileri sosyal ortamda arkadaşları tarafından onay almasını, beğenilmesini göstererek vurgulanabilir.

Çalışma, referans gruplarının satın alma kararlarına olan etkisine yönelik bir bakış açısı sunmasına rağmen, bir takım kısıtlara sahiptir. Bu kısıtlardan en önemlisi, araştırmanın evren ve örneklemi ile ilgilidir. Araştırma sadece Süleyman Demirel Üniversitesi öğrencilerine yönelik gerçekleşmiştir. Elde edilen sonuçların genellenmesi söz konusu değildir. Ancak, bu çalışmanın genişletilmesi için çeşitli yollar düşünülebilinir. Birincisi, gelecekteki çalışmalarda, genç yetişkinlerin ürün seviyesindeki kararlarına ek olarak marka düzeyindeki kararları üzerindeki etkisinin yansıması araştırılabilinir. Bu tür bir çalışma referans grupları içerisinde barındıran (aile, biçimsel sosyal gruplar) diğer öğeleri kapsayan bir uygulamayla genişletilebilinir. Son olarak araştırmacılar tarafından alkol, uyuşturucu ve sigara gibi gençlere zararlı olarak algılanan ürünlerdeki referans grubu etkileri araştırılabilinir. 


\section{Kaynakça}

Akçakanat, T., Çarıkçı, i. ve Dulupçu, M. A. (2010). Üniversite Öğrencilerinin Bulundukları il Merkezine Ekonomik Katkıları ve Harcama Eğilimleri: Isparta 2003-2009 Yılları Örneği. SDÜ Fen Edebiyat Fakültesi Sosyal Bilimler Dergisi, Aralık, 22, 165-178.

Arlı, E. (2012). Müşterilerin Kulaktan Kulağa Iletișime Bağlı Satın Alma Kararları Üzerinde Referans Gruplarının Etkisi: Deniz Turizm İşletmeciliği Üzerine Bir Araştırma. Uluslararası Yönetim iktisat ve Işletme Dergisi, 8 (17), 155-170.

Aydın, S. (2009). Kişisel ve Ürün Temelli Yenilikçilik: Cep Telefonu Kullanıcıları Üzerine Ampirik Bir Uygulama. Doğuş Üniversitesi Dergisi, 10 (2), 188-203.

Balcı, A. (2001). Sosyal Bilimlerde Araştırma: Yöntem, Teknik ve ilkeler. Ankara: Pegema Akademi Yayıncılık.

Bearden W. O. ve Etzel, M. J. (1982). Reference Group Influence on Product and Brand Purchase Decisions. Journal of Consumer Research, 9 (2), 183-194.

Bristol, T. ve Mangleburg, T. F. (2005). Not Telling The Whole Story: Teen Deception in Purchasing. Journal of the Academy of Marketing Science, 33 (1), 79-95.

Carter, D. S. G., Bennetts, C. ve Carter, S. M. (2003). "We're Not Sheep": Illuminating the Nature of the Adolescent Peer Group in Effecting Lifestyle Choice. British Journal of Sociology of Education, 24 (2), 225-241.

Childers, T. L. ve Rao, A. R. (1992). The Influence of Familial and Peer-Based Reference Groups on Consumer Decisions. Journal of Consumer Research, 19 (2), 198-211.

Chuang, S. C., Cheng, Y. H. ve Hsu, C. T. (2012). The Influence of Suggestions of Reference Groups in The Compromise Effect. Journal of Economic Psychology, 33 (3), 554-565.

Çakır, V. (2007). Tüketici Illgilenimini Ölçmek. Selçuk Illetişim, 4 (4), 163-180.

Çilingir, Z. ve Yıldız, S. (2010). Tüketicilerin Ürünlere Olan İlgileniminin Marka Sadakati Üzerindeki Etkisi: Sembolik Nitelikteki Bir Ürün Grubu İçin İstanbul Ilii Pilot Çalışması. ZKÜ Sosyal Bilimler Dergisi, 6 (11), 79-100.

Demir, M. Ö. (2011). Risk Algısının Marka Sadakatine Etkisi: Cep Telefonları Kategorisinde Bir Uygulama. Ege Akademik Bakış, 11 (2), 267-276.

Eskiler, E., Küçükibiş F. ve Soyer, F. (2016). Genç Tüketicilerin Satın Alma Davranışları Üzerine Rol Model Etkisi: Marka Duyarlıı̆ı Aracılık Rolü. ERPA International Congresses on Education 2016, Sarajevo / Bosnia and Herzegovina, 709-715. 
Eze C. U., Chin, C. H. H. ve Lee, C. H. (2012). Purchasing Designer Label Apparels: The Role of Reference Groups. Asian Journal of Business Research, 2 (2), 52-74.

Gönüllü, M. (2001). Grup ve Grup Yapısı. Cumhuriyet Üniversitesi Iktisadi ve Idari Bilimler Dergisi, 2 (1), 191-201.

Harari, T. T. ve Hornik, J. (2010). Factors Influencing Product Involvement Among Young Consumers. Journal of Consumer Marketing, 27 (69), 499-506.

Haroon, M. Z. ve Haq, N. M. A. (2015). Impact of Role Model on Behavioral and Purchase Intentions Among Youngsters: Empirical Evidence from Karachi, Pakistan. Journal of Management Sciences, 2 (2), 242-254.

Huang, S. C. ve Shu, C. C. (2008). The Influence of Global Mass Media and Reference Group on Consumer Attitude Toward Global Brands: The Case of College-Educated Chinese Youth. International Congress Marketing Trends, Annual Conference in Venice, January 17th - 19th.

Hsu, C. H. C., Kang, S. K. ve Lam, T. (2006). Reference Group Influences Among Chinese Travelers. Journal of Travel Research, 44 (4), 474-484.

İşçi, M. (1999). Davranış Bilimleri. İstanbul: Der Yayınları.

Kandemir, D., Atakan, S. S. ve Demirci, C. (2013). Il gilenim Kavramı ve Türkçe İlgilenim Ölçeklerinin Değerlendirilmesi: Tüketici İlgilenimi, Sürekli İlgilenim ve Satın Alma Kararı Illgilenimi. Iktisat Işletme ve Finans Dergisi, 28 (330), 21-48.

Karamustafa K. ve Erbaş, E. (2011). Satın Alma Karar Sürecinde Algılanan Risk: Paket Turlara Yönelik Bir Araştırma, Tüketici ve Tüketim Araştırmaları Dergisi, 3 (1), 103-144.

Kavak, B. (2008). Pazarlama Araştırmaları: Tasarım ve Analiz. Ankara: Hacettepe Üniversitesi Yayınları.

Kulviwat, S., Bruner, G. C. ve Shuridah, O. A. (2009). The Role of Social Influence on Adoption of High Tech Innovations: The Moderating Effect of Public/Private Consumption. Journal of Business Research, 62, 706-712.

Koç, E. (2012). Tüketici Davranışı ve Pazarlama Stratejileri, Global ve Yerel Yaklaşım. Ankara: Seçkin Yayıncılık.

Makgosa, R. ve Mohube, K. (2007). Peer Influence on Young Adults' Products Purchase Decisions. African Journal of Business Management, 1 (2), 64-71.

Mangleburg, T. F., Doney, P. M. ve Bristol, T. (2004). Shopping With Friends And Teens' Susceptibility to Peer Influence. Journal of Retailing, 80, 101-116.

Martin, C. A. ve Bush, A. J. (2000). Do Role Models Influence Teenagers' Purchase Intentions and Behavior?. Journal of Consumer Marketing, 17 (5), 441454.

Odabaşı, Y. (1998). Tüketici Davranışı ve Pazarlama Stratejisi. Eskişehir: Anadolu Üniversitesi Yayınları. 
Özkalp, E. (2000). Davranış Bilimine Giriş I. Eskişehir: Anadolu Üniversitesi Yayınları.

Park, V. ve Lessig, P. (1977). Students and Housewives: Differences in Susceptibility to Reference Group Influence. Journal of Consumer Research, 4 (2), 102-110.

Pentina, I., Prybutok, V. R. ve Zhang, X. (2008). The Role of Virtual Communities as Shopping Reference Groups. Journal of Electronic Commerce Research, 9 (2), 114-136.

Scully, K. ve Moital, M. (2016). Peer Influence Strategies in Collectively Consumed Products (Events and Festivals): An Exploratory Study Among University Students. Young Consumers, 17 (1), 46-63.

Şener, H. Y. ve Tunçbilek, S. (2014). Genç Tüketicilerin Referans Gruplara Üyeliklerinin Sembolik Tüketime Etkisi. Akademik Bakış Dergisi. Ocak-Şubat 2014. Erişim 28 Ekim 2015, http://www.akademikbakis.org

Şerif, M. ve Şerif, C. W. (1996). Sosyal Psikolojiye Giriş. (M. Atakay ve A. Yavuz Çev.). İstanbul: Sosyal Yayınları.

Tek, Ö. B. (1998). Pazarlama Illkeleri, Global Yönetimsel Yaklaşım Türkiye Uygulamaları. İstanbul: Cem Ofset Matbaacılık.

Ünal, S. ve Erciş, A. (2007). Genç Pazarın Satın Alma Tarzlarının Belirlenmesi Üzerine Bir Araştırma. Atatürk Üniversitesi Iktisadi ve Idari Bilimler Dergisi, 21 (1), 321-336.

Yang, J., He, X. ve Lee, H. (2007). Social Reference Group Influence on Mobile Phone Purchasing Behaviour: A Cross-Nation Comparative Study. International Journal Mobile Communications, 5 (3), 319-338. 